Т.М. КОСТЕНКО

\title{
ПСИХОЛОГІЧНИЙ СУПРОВІД СІМЕЙ ОСІБ З ІНВАЛІДНІСТЮ ПО ЗОРУ
}

\author{
(C) Костенко Т.М., 2020 \\ https://orcid.org/0000-0002-4976-1236 \\ http://doi.org/10.34142/2312-2471.2020.63.10
}

На становлення особистості з інвалідністю в суспільстві, соизілізацію та інтеграцію головним чином впливають такі чинники, як сім'я, сочіальні інститути, в межах яких та чи інша людина виконує свої ролі й функиії. Найбільш значимим з них для людей з інвалідністю по зору є сім'я. Сприятливі умови для інтеграчії людини з інвалідністю по зору в суспільство, підвищення соиіального статусу створює саме сім'я. Мета статті полягає у висвітленні проблеми психологічного супроводу сімей з інвалідністю по зору та обтрунтуванні необхідності побудови психологічної підтримки таких сімей в Україні. В статті використовувались наступні методи: аналіз, порівняння та систематизачія науково-методичних, вітчизняних та зарубіжних досліджень із спеціальної психології. В роботі виокремлено основні проблеми сімей осіб $з$ інвалідністю по зору - проблеми одного з подружжя, в якого є порушення зору та спільні проблеми сім'ї. Виділені основні труднощі в парах, які включають партнера з інвалідністю по зору, визначені основні завдання на їх подолання на трьох рівнях: когнітивному - підвищення рівня обізнаності про самого себе $i$ партнера; емоційному - зміна емоційного стану партнерів і формування у них емоиійної близькості; поведінковому - формування умінь $i$ навичок, що підвищать ефективність взаємодії партнерів один з одним. Обгрунтовано основні принципи психологічного супроводу сім'ї з інвалідністю по зору та описана орієнтовна програма психологічного супроводу, яка включає: психологічне консультування; психологічну діагностику; психологічну корекцію; психотерапевтичну допомогу; сочіально-психологічний тренінг; психологічну профілактику; психологічний патронаж. Проблема психологічного супроводу сімей осіб з інвалідністю по зору в Україні потребує подальших науковопрактичних розвідок. Людина 3 інвалідністю по зору часто від непоінформованості про можливість отримати необхідну психологічну допомогу та підтримку залишається на одиниі зі своїм проблемами. Розроблена програма супроводу таких сімей має бути включена в комплексну систему реабілітаиії, зокрема, - психологічної реабілітації.

Ключові слова: психологічний супровід, особи з інвалідністю по зору, психологічна підтримка. 
Kostenko T.M. Psychological Support for Families with Visual Disability Persons

A disability person's formation in a society, socialization and integration are mainly influenced by such factors as family, social institutions, where a person performs roles and functions. The most important for people with visual impairments is a family. Favourable conditions for the integration of a visually impaired person into society, raising social status are created by a family. The article purpose is to highlight the problem of psychological support for families with visual disabilities and justify the need to build psychological support for such families in Ukraine. The following methods were used in the article: analysis, comparison, and systematization of scientific-methodical, Ukrainian and foreign researches in special psychology. The main family problems of visually impaired people are highlighted in the article; they are the problems of a spouse who has visual impairments and common family problems. The main difficulties in couples that include a partner with a visual disability and the main tasks for overcoming are identified at three levels: cognitive one, raising the level of self-awareness and partner's awareness; emotional one, changing partners' emotional state and the formation of their emotional intimacy; behavioral one, forming skills and abilities that will increase the effectiveness of interaction between partners. The basic principles of psychological support of a family with visual impairment are substantiated and the approximate program of psychological support is described. It includes psychological counselling; psychological diagnosis; psychological correction; psychotherapeutic care; sociopsychological training; psychological prevention; psychological patronage. The conclusion is the problem of a psychological family support of visually impaired people in Ukraine is insufficiently studied and needs further scientific and practical research. A person with a visual impairment is often left alone with his/her problems due to the lack of information about the possibility of receiving the necessary psychological help and support. The developed program for the support such families should be included in a comprehensive system of rehabilitation, in particular, in psychological rehabilitation.

Key words: psychological support, persons with visual disabilities, psychological assistance.

Постановка проблеми. Сьогодні не лише говориться про інтеграцію в суспільство осіб з інвалідністю по зору, а й відбуваються зміни у відношенні суспільства і держави до людей з інвалідністю, визначаються їх права щодо надання рівних можливостей у різних сферах життя. Сучасна демократична держава має характеризуватися зростанням тенденцій до гуманізації, до безбар'єрних шляхів соціальної інтеграції осіб з інвалідністю, до забезпечення рівних прав і можливостей.

На становлення особистості з інвалідністю в суспільстві, соціалізацію та інтеграцію головним чином впливають такі чинники, як сім'я, соціальні 
інститути, в межах яких та чи інша людина виконує свої ролі і функцї̈, суспільство в цілому, що надає людині певні права.

Найбільш значимим 3 них для людей 3 інвалідністю по зору $\epsilon$ сім'я. Сприятливі умови для інтеграції людини з інвалідністю по зору в суспільство, підвищення соціального статусу створює саме сім'я. Сім'я як одна з підсистем соціального простору людини з зоровою депривацією, відіграє велику роль в організації сприятливого середовища, оточення, спеціального обладнання, створення сприятливого клімату. Саме члени сім'і $\epsilon$ незамінними помічниками в створенні умов для повноцінного життя людини 3 інвалідністю по зору в період адаптації та соціального підйому.

За даними Всесвітньої організації охорони здоров’я, у світі налічується майже понад 285 мільйонів людей із порушенням зору, з них 45 мільйонів тотально незрячі. В Україні точної офіційної статистики щодо кількості людей 3 порушеннями зору немає, але за неофіційними даними, - це приблизно 100 тисяч людей і 22\% молодь. Як і кожна людина, люди 3 інвалідністю по зору прагнуть щастя, розуміння і особистісного благополуччя.

Втрата зору призводить до певної перебудови психіки i поведінки, будується нова система переживань, порушується звичне стереотипне світосприйняття, включається новий адаптаційний режим. На початкових етапах цей процес супроводжується різкими, негативними емоційними проявами пригніченості, тривоги, страху.

В структурі особистості відбувається трансформація окремих ознак особистісного неблагополуччя в стійкі психічні стани, які в подальшому можуть накласти відбиток на всю систему життєдіяльності. У значної частини осіб 3 інвалідністю по зору формується стигматизована («інвалідизована») ідентичність 3 деструктивними стратегіями соціального функціонування.

Аналіз останніх досліджень і публікацій. Сімейні, близькі стосунки осіб 3 інвалідністю по зору $\epsilon$ метою життя більшості 3 них, це впливає на особистісне благополуччя партнерів, на їх задоволеність стосунками, на психологічний клімат всередині, на обмеження життєдіяльності, пов'язаною 3 інвалідністю [2].

Не зважаючи на актуальність зазначеної проблеми, в Україні вона досліджена дотично 3 іншими проблемами осіб 3 інвалідністю по зору. Так, дана проблема розглядалася в контексті розвитку, виховання та навчання (Л.Вавіна), соціалізації та інтеграції (Є. Клопота [2]), психологічних особливостей осіб з зоровою депривацією (В. Кобильченко [3]), вивчався корекційно-розвитковий напрямок (Т. Гребенюк, І. Гудим, Т. Дегтяренко [1]), досліджувалася психологія особистості з порушеннями зору (Т. Костенко [4], С. Синьова [5], О. Таран ін). Проблема сімей осіб 3 інвалідністю вивчалася, здебільшого, зарубіжними співавторами T.Reverson, K.Kayser, G.Bodenmann [7], співавторами C.Vash, N.Crewe [8].

Так, за даними зарубіжних досліджень критеріями благополуччя сім’ї осіб 3 інвалідністю є: задоволеність стосунками, спосіб реагування на кризові 
ситуації, рівень адаптації, самоприйняття, позитивні відносини 3 оточуючими, автономія, висока функціональність сім'і [7].

Виділення невирішених раніше частин загальної проблеми. Питання психологічного супроводу сімей 3 інвалідністю по зору досі потребує грунтовного вивчення та впровадження в практику експериментальних адаптованих та модифікованих методик та технік роботи. Потребує розробки та реалізації системний підхід до проблеми психологічного супроводу всієї родини в цілому. Зважаючи на актуальність визначеної проблеми серед сімей людей з інвалідністю по зору, вважаємо за необхідне зробити детальний аналіз можливих психологічної допомоги таким сім'ям.

Формування цілей статті. Основною метою статті $є$ проаналізувати та виокремити основні проблеми сімей осіб 3 інвалідністю по зору, систематизувати основні труднощі в парах, які включають партнера 3 інвалідністю по зору та визначити основні завдання на їх подолання на трьох рівнях: когнітивному, емоційному, поведінковому. А також обгрунтувати основні принципи психологічного супроводу сім'і з інвалідністю по зору для орієнтовної програми психологічного супроводу.

Виклад основного матеріалу дослідження. В 2019 році за ініціативи автора та сприянню ГО АДПУ було проведено соціальне опитування, метою якого було виявлення й аналіз соціальних бар'єрів мобільності людей 3 інвалідністю по зору. Вік учасників соціального опитування - від 18 до 65 років. Загальна кількість респондентів 876 чоловік. Аналіз отриманих даних засвідчив: 11,3 \% людей 3 інвалідністю по зору перебувають в цивільному шлюбі, 39,5\% не перебували і не перебувають у шлюбі, 12, 6\% - розлучені, 36,6\% - в законному шлюбі.

Неочікуваним результатом після оприлюднення результатів проведеного опитування було звернення респондентів до Асоціації за психологічною допомогою та підтримкою в контексті вирішення проблеми в середині сім’ї, або ж допомога була потрібна у подоланні психологічних бар’єрів у створенні сім’ї. Психологічна допомога передбачала виявлення запиту клієнтів та надання первинної психологічної допомоги. Таким чином, ми змогли далі досліджувати категорію сімей осіб з інвалідністю по зору.

Виявилося, що сім’ї поділяються на склад: 1) і чоловік, і дружина мають інвалідність по зору (порушення зору); 2) тільки один з членів сім’і має інвалідність по зору (порушення зору), здебільшого отриману внаслідок певних життєвих ситуацій.

Вивчаючи категорію сімей, де один з членів є незрячим або з порушеннями зору, ми виділили дві основні категорії проблем подружжя. Перша категорія це проблеми одного з подружжя, в якого $є$ порушення зору: людина відчуває себе в сім'ї зайвою, постійне відчуття провини перед своїми зрячими родичами; відчуття безпорадності та дискомфорту; відчуття невпевненості у завтрашньому дні; прояв агресії до оточуючих; аутоагресія. 
Майже $40 \%$ опитаних інвалідів по зору знаходиться в психологічній або фізичній залежності від членів своїх сімей. Перебування в такому кліматі й породжує замкнутість, пасивність та інколи агресивність.

Друга категорія - це спільні проблеми сім'ї: відповідальність за незрячого або з порушеннями зору; обмеженість у проведенні вільного часу; виконання обов'язків по догляду та надання допомоги.

$€$ випадки, коли людина з інвалідністю залишається наодинці не тільки зі своїми внутрішніми проблемами, а й проблемами не надання необхідної фізичної допомоги в колі сім'ї. Тому, щоб не впасти в депресію, пережити психологічну травму і почати жити знову, необхідна допомога фахівця психолога або до психіатра, в залежності від серйозності проблеми.

Допомога психолога здійснюється за кількома напрямками. У першу чергу психолог здійснює емоційну підтримку. Після чого намагається сформувати нові конструкти в мисленні людей з порушеннями зору, допомагає знайти ресурсні можливості особистості, а на заключному етапі психолог допомагає закріпити нові поведінкові конструкти за допомогою тренінгів [3].

В ході консультування сімейних пар, в яких один 3 подружжя має інвалідність по зору, та пар, в яких чоловік та жінка мають інвалідність по зору, автором виявлено наступні особливості. В більшості сімей простежується любов, повага і прихильність. В парі панує взаєморозуміння та прийняття один одного. Кожен в парі є особистістю i, коли особистість приймається без намагання іï «переробити» під себе, то така сім'я характеризується високим рівнем особистісного благополуччя. Такі пари не дозволяють втручатися в свої сімейні стосунки батькам, родичам, друзям знайомим - всі проблемні ситуації вирішуються самостійно. Так, сім'ям людей 3 інвалідністю по зору притаманний весь спектр не лише подружніх, а й батьківських відносин. У них $\epsilon$ мрії, плани та реалії, як і в інших сім'ях.

Однак бувають випадки між подружжям, коли має місце володіння, домінування, влади і підпорядкування, але це все завуальовано романтичною любов'ю, турботою. Це в свою чергу відмежовує людей 3 інвалідністю від ресурсів суспільства, змушує ігнорувати потреби один одного, руйнує стосунки. В таких сім'ях є випадки психологічного тиску, який проявляється від початку спільного життя. Найчастіше, люди з інвалідністю по зору в таких ситуаціях, змушені залишатися в сім'і і терпіти, оскільки перебуває в економічній залежності й не бачать іншого виходу. Постає нелегкий вибір жити в сім’ї чи залишитися одному. Іноді в цьому виборі переважає почуття обов'язку, необхідності, почуття відповідальності або провини.

Якщо порівнювати ці два типи сімей, то конфлікти виникають в сім'ях здебільшого там, де порушуються особисті кордони як самим подружжям, так $\mathrm{i}$ родичами. Батьки, які гіперопікують своїх вже дорослих «дітей», створюють своєрідний простір залежності, що негативно впливає на особистісне благополуччя кожного в парі, та на сім'ю в цілому. Тому, ми вважаємо, супровід родин потребує окремого детального вивчення та допомоги в налагодженні підтримуючого середовища в сім'ях осіб людей з інвалідністю по 
зору, що буде наступним етапом в розробці програми психологічного супроводу.

Також, автором в практиці консультування були виділені основні труднощі в парах, які включають партнера $з$ інвалідністю по зору: неволодіння повною інформацією про свій можливий потенціал та фізичні можливості партнера 3 інвалідністю, що негативно впливає на побудову взаємопідтримки пари взагалі; недооцінка здібностей i можливостей партнера 3 інвалідністю, що проектує відсутність підтримки або формальність; нездоровий розподіл відповідальності в парі, тобто здоровий партнер бере на себе більше відповідальності, що призводить до зниження самоактивності партнера 3 інвалідністю; прагнення здорового опікати і доглядати за партнером 3 інвалідністю знижує рівень стресостійкості, що призводить до психологічної напруженості в подоланні кризових ситуацій.

Наступним етапом вивчення проблеми психологічного супроводу сімей 3 інвалідністю по зору було визначення завдань, які сприятимуть подоланню виявлених труднощів.

1. Формування у кожного з партнерів особистісного благополуччя.

2. Робота з емоційними станами особистості кожного партнера та пари, як єдиного цілого.

3. Створення умов для реалізації ефективної поведінки в кризових життєвих ситуаціях.

4. Пізнання партнера, адаптація до його особливостей.

5. Сприяння емоційній близькості пари.

Вирішувати визначені завдання можливо на трьох рівнях: когнітивному підвищення рівня обізнаності про самого себе і партнера; емоційному - зміна емоційного стану партнерів i формування у них емоційної близькості; поведінковому - формування умінь і навичок, що підвищать ефективність взаємодії партнерів один з одним.

Основними принципами психологічного супроводу сім'ї з інвалідністю по зору ми виділили наступні: рекомендаційний (необов'язковий для виконання) сприяння прояву самостійності пари у розв'язанні проблеми; пріоритетний результат залежить від рівня готовність подружжя до роботи 3 фахівцем, зацікавленості в ефективному вирішенні проблем; безперервний - психолог надає допомогу i підтримку парі до вирішення проблеми; мультидисциплінарний - використання різних способів, методів і засобів для вирішення проблеми та підключення інших фахівців; співробітницький налагодження співпраці і взаємодії не тільки між сім'єю і психологом, а й безпосередньо між подружжям.

При відсутності своєчасної психологічної допомоги відбувається трансформація окремих ознак особистісного неблагополуччя (психологічних реакцій на втрату чи погіршення зору) в стійкі психічні стани, які в подальшому можуть призвести не тільки до істотного погіршення благополуччя кожного члена сім’ї окремо, але і накласти відбиток на систему життєдіяльності сім’i. 
Тому нами пропонується орієнтовна програма психологічного супроводу сімей осіб з інвалідністю по зору, яка включає: психологічне консультування; психологічну діагностику; психологічну корекцію; психотерапевтичну допомогу; соціально-психологічний тренінг; психологічну профілактику; психологічний патронаж.

Психологічне консультування - спеціально організована взаємодія між психологом і сім'єю (або з кожним членом сім’ї - окремо), яка потребує психологічної допомоги, 3 метою вирішення проблем. Психологічне консультування включає в себе: виявлення значимих для людини 3 порушеннями зору проблем соціально-психологічного змісту в галузі міжособистісних взаємин, спілкування, поведінки в сім'ї, в групі (навчальної, трудової), в суспільстві, при вирішенні різних конфліктних ситуацій, проблем особистісного зростання, соціалізації та інших.

До цього додається обговорення виявлених проблем з метою розкриття $\mathrm{i}$ мобілізації внутрішніх ресурсів для їх подальшого вирішення; надання первинної психологічної допомоги у вирішенні виявлених соціальнопсихологічних проблем, у відновленні адекватних соціальних відносин і в формуванні позитивної установки на соціально-психологічну реабілітацію; попереднє визначення типу (виду) необхідної в подальшому послуги 3 психологічної реабілітації, уточнення іiі змісту в кожному конкретному випадку.

Психологічна діагностика сім'ї осіб 3 інвалідністю по зору (осіб 3 порушеннями зору) полягає у: виявленні психологічних особливостей, можливостей, визначенні специфіки іiі поведінки і взаємин з оточуючими, можливості соціальної адаптації з використанням психодіагностичних методів та аналізі отриманих даних в цілях побудови психологічного супроводу всієї сім'ї.

Психологічна діагностика людей з порушеннями зору включає в себе оцінку: стану вищих психічних функцій і динаміки психічної діяльності, що лежать в основі формування соціального інтелекту і соціально-психологічної компетентності людини з порушеннями зору; стану емоційно-вольової сфери (нестійкість, ригідність, пластичність, запальність, рівень тривожності), що відображає суб'єктивну реакцію людини з порушеннями зору, впливу на соціальне оточення у вигляді опису виявлених порушень і ступеню їх вираженості.

До цього додається оцінка особливостей особистісних якостей людини 3 порушеннями зору (включаючи ціннісні орієнтації, мотиваційну сферу, самооцінку, рівень домагань), що відображають сукупність внутрішніх умов, через які переломлюються зовнішні впливи, та визначають спосіб взаємодії людини з порушеннями зору з соціумом.

Психологічна діагностика включає в себе наступні етапи:

а) аналіз вихідної документації на обстежуваного (медичної та соціальної); б) конкретизацію цілей і завдань психодіагностики та планування іiї програми;
в) співбесіду;
г) проведення
психологічної
реабілітаційно-експертної 
діагностики; д) обробку i аналіз психодіагностичних даних; е) підготовку висновку за результатами психодіагностики; ж) розробку психологічної складової індивідуальної програми психологічного супроводу сім’ї осіб 3 інвалідністю по зору з конкретизацією змісту і спрямованості послуг.

Психологічна корекція полягає в активному психологічному впливі, направленому на подолання або послаблення відхилень у розвитку, емоційному стані i поведінці людини 3 порушеннями зору 3 метою: відновлення оптимального функціонування психологічних механізмів, що забезпечують повноцінне включення людини 3 порушеннями зору в різноманітні сфери соціальних відносин і життєдіяльності; формування соціально-психологічної компетентності у відповідності з віковою нормою i вимогами соціального середовища; профілактики небажаних негативних тенденцій в особистісному розвитку людини з порушеннями зору, соціалізації на всіх рівнях соціуму.

Психологічна корекція переважно орієнтована на збережені, але недостатні для успішної соціальної життєдіяльності психічні функції. Психологічна корекція реалізується у вигляді циклів занять, що забезпечують створення необхідних умов для виправлення та розвитку психічних функцій і якостей, пов'язаних із соціальною адаптацією людини 3 порушеннями зору. Форма проведення - різні за тематикою і складністю сюжету рольові ігри, навчальні заняття, виконання тестових завдань зі зворотним зв'язком та інші.

Психотерапевтична допомога являє собою систему психологічних впливів, спрямованих на зміну ставлення як до соціального оточення, так i до своєї власної особистості, а також на формування позитивного психологічного мікроклімату в родині. В якості методів психотерапевтичного впливу застосовуватимуться: арт-терапія, психодрама, сімейна психотерапія, позитивна терапія та інші методи терапії, якими володіє психолог.

Методи підбиратимуться таким чином аби сприяти підвищенню компетентності людини 3 порушеннями зору у формуванні гармонійних міжособистісних відносин, вдосконаленню здатності до самопізнання та саморегуляції. Психотерапевтичні сеанси (сесіі) проводять у груповій або індивідуальній формі.

Психологічна профілактика полягає в: підвищенні психологічної компетентності; формуванні потреби (мотивації) використовувати ці знання для роботи над собою, над своїми проблемами соціально-психологічного змісту; створення умов для повноцінного психічного функціонування особистості людини з порушеннями зору (усунення або зниження факторів психологічного дискомфорту в родині, на роботі і в інших соціальних групах), для своєчасного попередження можливих психічних порушень, обумовлених, в першу чергу, соціальними відносинами.

Психологічна профілактика націлена на раннє виявлення станів соціальнопсихологічної дезадаптації і систематичного контролю за іiі проявами, на забезпечення i підтримку психологічного благополуччя, попередження можливих порушень системи взаємовідносин в мікро- i макросоціумі за 
рахунок актуалізації психологічних механізмів соціальної адаптації та компенсації людей з порушеннями зору.

Психологічний тренінг полягає в активному психологічному впливі, спрямованому на зняття 3 людини 3 порушеннями зору наслідків психотравмуючих ситуацій, психологічної напруги, на розвиток і тренування окремих психічних функцій i якостей особистості, ослаблених в силу захворювання, травми або умов соціального середовища, але необхідних для успішної адаптації в нових соціальних умовах, на формування здібностей, що дозволяють успішно виконувати різні соціальні ролі (сімейні, професійні, громадські та інші) і мати можливість бути включеним у різні галузі соціальних відносин і життєдіяльності.

Психологічний тренінг проводять у вигляді системи вправ, групової дискусії, рольової та ділової гри, психогімнастичних і релаксаційних вправ, які моделюють спеціальні умови діяльності для тренування певних психічних функцій і якостей, відповідальних за соціальну адаптацію людини 3 порушеннями зору.

Психологічний патронаж полягає в систематичному спостереженні за людиною з порушеннями зору для своєчасного виявлення ознак психічного дискомфорту, обумовлених проблемами адаптації людини з порушеннями зору в сім'і, на виробництві, в соціумі в цілому, та надання, при необхідності психологічної допомоги: по корекції і стабілізації сімейних відносин (психологічного клімату в сімі); корекції міжособистісних відносин у колективі, трудовому колективі, корекції відносин субординації; організації навчання членів сім'ї методам психологічної взаємодії 3 людиною 3 порушеннями зору; надання психологічної допомоги сім'ї в цілому як найближчого соціального оточення людини 3 порушеннями зору. Соціальнопсихологічний патронаж спрямований, насамперед, на формування у людини 3 порушеннями зору адекватних моделей соціальної поведінки.

Висновки. 3 огляду на вищезазначене, маємо підставу стверджувати, що сім'я осіб 3 інвалідністю по зору мало чим відрізняється від середньостатистичної сім'ї в плані сімейного благополуччя. Але в ній є певні зони ризику, які формуються соціальними факторами і відсутністю вчасної психологічної та соціальної підтримки.

Отже, уявлення про сім'ю як про агента соціалізації далеко не нові, проте розгляд особливостей внутрішньо-сімейних відносин, як фактору впливу i одночасно індикатора особливостей соціальної мобільності людини 3 інвалідністю по зору, свідчить про новизну поєднання фундаментальних теоретичних побудов з практико-орієнтованими дослідженнями.

Результати дослідження можуть бути використані в організації психологічного супроводу сімей осіб 3 інвалідністю по зору та діяльності реабілітаційних центрів. Створення умов для повноцінного сімейного функціонування, незважаючи на обмеження життєдіяльності, може розглядатися як мета реабілітації та система психологічного супроводу таких сімей. 
Перспективи подальших розвідок у цьому напрямі. В подальшому планується продовження проведення психологічного супроводу сімей осіб 3 інвалідністю по зору та наукові розвідки у цьому напрямку.

\section{Jimepamypa}

1. Дегтяренко T.M. Корекційно-реабілітаційна діяльність: стратегія управління. Суми: Видавець ПП Кочубей Н.В., 2011. 432 с.

2. Клопота Є.А. Особливості процесу інтеграції в суспільство осіб 3 глибокими порушеннями зору. Актуальні проблеми навчання та виховання людей з особливими потребами. 2015. № 12 (14). С. 142-155.

3. Кобильченко В.В. Проблема супроводу в науковій та методичній психолого-педагогічній літературі. Дефектологія. Особлива дитина: навчання і виховання. 2010. №2. С. 31-36.

4. Костенко Т.М., Гошовський В.I. Тифлоприлади в освітньому процесі: роль, функції, забезпечення. Освіта осіб з особливими потребами: шляхи розбудови. 2019. Вип. 14. С. 91-95.

5. Синьова Є.П. Проблеми соціальної реабілітації зору. Соиіальна політика і соиіальна робота. 1998. № 1. С.109-115.

6. Прохоренко Л.І., Романенко О.В. Особливості класифікації об'єктів інформаційного поля дітьми із затримкою психічного розвитку. Інформаційні технології і засоби навчання. 2019. т. 74, № 6, 266-277. URL: https://www.researchgate.net/publication/338334638_OSOBLIVOSTI_KLASIFIKA CII_OB'EKTIV_INFORMACIJNOGO_POLA_DITMI_IZ_ZATRIMKOU_PSIHIC NOGO_ROZVITKU

7. Reverson T., Kayser K., Bodenmann G. Emerging perspectives on couples coping with stress. Washington: American Psychological Association. 2005.

8. Vash C.L., Crewe, N.M. Psychology of disability. New York: Springer Publishing Company. 2004.

\section{References}

1. Dehtiarenko, T.M. (2011). Korektsiino-reabilitatsiina diialnist: stratehiia upravlinnia: monohrafiia. [Correctional and rehabilitation activities: management strategy: monograph]. Sumy: Vydavets PP Kochubei N.V. (in Ukrainian).

2. Klopota, Ye.A. (2015). Osoblyvosti protsesu intehratsii v suspilstvo osib $\mathrm{z}$ hlybokymy porushenniamy zoru [Features of the process of integration into society of persons with profound visual impairments]. Aktualni problemy navchannia ta vykhovannia liudei z osoblyvymy potrebamy. Current problems of education and upbringing of people with special needs, 12(14), 142-155. (in Ukrainian).

3. Kobylchenko, V.V. (2010). Problema suprovodu $v$ naukovii ta metodychnii psykholoho-pedahohichnii literaturi [The problem of support in the 
scientific and methodological psychological and pedagogical literature]. Defektolohiia. Osoblyva dytyna: navchannia i vykhovannia. Defectology. Special child: education and upbringing, 2, 31-36. (in Ukrainian).

4. Kostenko, T.M., \& Hoshovskyi, V.I. (2019). Tyfloprylady v osvitnomu protsesi: rol, funktsii, zabezpechennia. Osvita osib z osoblyvymy potrebamy: shliakhy rozbudovy [Naukovo-metodychnyi zbirnyk], 14, 91-95. (in Ukrainian).

5. Synova, Ye.P. (1998). Problemy sotsialnoi reabilitatsii zoru [Problems of social rehabilitation at dawn]. Sotsialna polityka i sotsialna robota. Social policy and social work, 1,109-115.

6. Prokhorenko, L.I., \& Romanenko, O.V. (2019). Osoblyvosti klasyfikatsii obiektiv informatsiinoho polia ditmy iz zatrymkoiu psykhichnoho rozvytku. Informatsiini tekhnolohii i zasoby navchannia, 74, 6, 266-277. [Elektronnyi resurs] Dostupno:https://www.researchgate.net/publication/338334638_OSOBLIVOSTI_KL ASIFIKACII_OBEKTIV_INFORMACIJNOGO_POLA_DITMI_IZ_ZATRIMKOU _PSIHICNOGO_ROZVITKU (in Ukrainian).

7. Reverson, T., Kayser, K., \& Bodenmann, G. (2005). Emerging perspectives on couples coping with stress. Washington: American Psychological Association.

8. Vash, C.L., \& Crewe, N.M. (2004). Psychology of disability. New York: Springer Publishing Company. 